Research Article

\title{
Effect of Storage Environments and Packaging on Physical and Cooking Attributes of Course and Aromatic Rice Varieties Grown in Pakistan
}

\author{
Nazeer Ahmed Lashari ${ }^{*}$, Saghir Ahmed Sheikh², Aijaz Hussain Soomro and ShamsuddinTunio ${ }^{3}$
}

${ }^{1}$ Nutrition Section, Ministry of Planning Development and Special Initiatives, PPMI Complex Street No 1 Sector H-8/1 Islamabad, Pakistan; ${ }^{2}$ Institute of Food Sciences and Technology, Faculty of Crop Production, Sindh Agriculture University, Tandojam; ${ }^{3}$ Faculty of Crop Production, Sindh Agriculture University, Tandojam, Sindh, Pakistan.

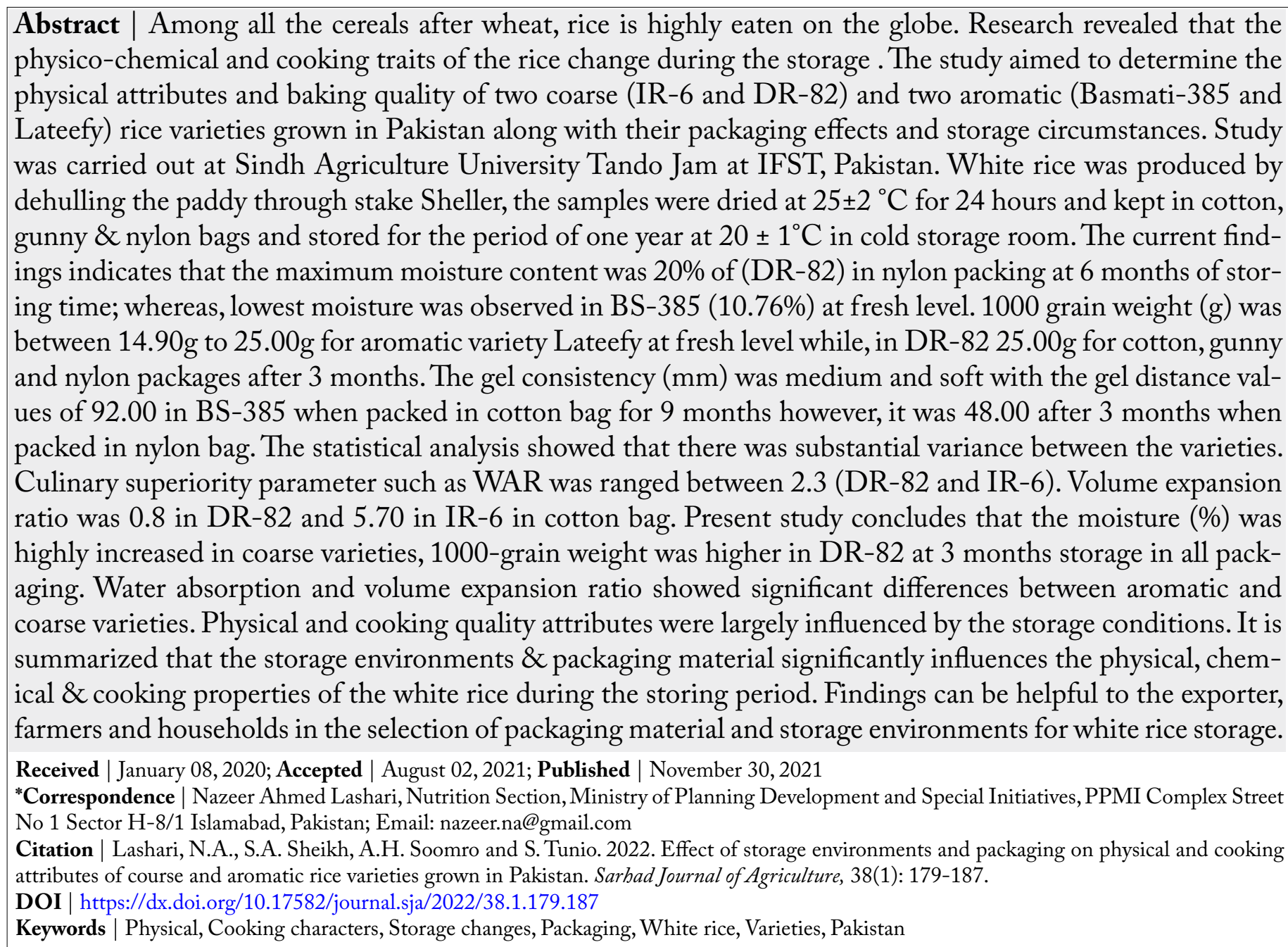

\section{Introduction}

$\mathrm{R}$ ice (Oryza sativa L.) is grown on nearby onetenth cultivatable land on the Earth (Khan et al.,
2013). More than one hundred countries in the world cultivate rice. In 2019, it was cultivated on about 162 million hectares area and produced approximately 755 million tons globally (FAOSTAT, 2019). Asia ac- 
counts for more than $90 \%$ worldwide rice production (Kumar and Prasad, 2013). It is the second frequently consumed food among all the cereals throughout the world. China, Indonesia, Pakistan, Vietnam and India are the major rice producing countries (Verma et al., 2015). Rice is highly consumed in Asia \& Africa continents, whereas, less in European Union (Vlachos and Arvanitoyannis, 2008). Out of total rice production more than $90 \%$ rice consumed by Asia and is staple food for most population which includes 560 million hungry persons (Mohanty, 2013). Rice production of Pakistan is around 6 million tonnes annually along with remining South Asia supplying 25\% paddy of the globe (Prasad et al., 2010). After wheat rice is our next staple crop. It is one of major exports for foreign exchange earnings in food group. In 201819, 2810 hectares were cropped, which produced 7202 thousand tons (GoP, 2019). Rice consists of $80 \%$ carbohydrates, $7-8 \%$ protein, 3\% fat and 3\% fiber ( Juliano, 1985). Rice is good source of micronutrients like magnesium, calcium, phosphorus riboflavin and niacin (Oko and Ugwa, 2011). Aromatic varieties are excessively used by the consumers because of superior attributes such as super fine slender grains, good culinary, fine flavor and enlargement during cooking (Bhattacharjee et al., 2002). Majority of the buyers prefer rice based on its aroma and in terms of aroma 'basmati' rice is the most desired one all over the world (Ahmad, 2001). Its cooking quality attributes like grain length \& extension throughout culinary, stickiness, \& length/breadth ratio are, also important to consumers. Basmati rice has very interesting cooking qualities i.e., non-waxy, non-glutinous, nonsticky and longest elongation after cooking (Thomas et al., 2013). The moisture, ash, fiber, protein, and fat content of coarse varieties ranges from 9.23-12.26, 0.67-3.81, 0.98-4.21 and 6.04-8.98, and 1.23-5.45 $\mathrm{g} / 100 \mathrm{~g}$, respectively (Kausar et al., 2020). Whereas, the aromatic varieties consists of carbohydrate, protein, fat, and ash content of 84.3, 9.4, 1.4, and 0.6 $\mathrm{g} / 100$ respectively (Gunathilaka et al., 2015). Market value of rice mainly depends on the grain appearance including shape/size of the kernel, translucency and chalkiness. Rice with the damaged eyes have unattractive look and little market value. Likewise, high chalkiness lower the market acceptability. Compared to other varieties, the market value of Basmati is very high due to its large grain size and linear elongation and lower chalkiness (Shamim et al., 2017). Throughout the storing, temperature $\&$ humidity are important characteristics that can define physical, chemical
$\&$ cooking attributes changes. Some basic sensory and chemical attributes are affecting rice properties specially during storage (Butt et al., 2008). Similarly, rice shows changes in physical appearance and aroma throughout its aging in storage (Tananuwong et al., 2011). Storage affects the grain quality and accountable for the difference in the look, milling, consumption, culinary, and dietary characteristics (Atungulu et al., 2019). It affects the moisture content, WAR, VER, grain elongation ratio, and amylose content (Butt et al., 2008). Moreover, physicochemical attributes of the rice are dynamic during the stowage environment with the passage of time. Research has shown that extension in storage time influenced elasticity with gradual decrease of recovery of cooking of rice which adhesion first increased and subsequently decreased. (Wang et al., 2017). The logic for more water requirement of aged rice is due to gelatinization of starch granules, therefore cooking will be delayed as compared to fresh rice (Katekhong and Charoenrein, 2012). Water soaking prior to cooking diminished cooking time by 10 minutes and enhanced dimensional variations of cooking rice (Hirannaiah et al., 2011). Rice is most significant food crop grain and essential component of our diet, it is most needed way of food storage at household level with multilateral benefits like, high caloric availability \& enhanced shelf life. Buyers are more conscious about superiority of rice they consume. The grain look, flavor, nutritious benefits \& culinary attributes are key elements for assessing quality. Storage environment is an effective element impacting the rice physicochemical characteristics of the gain. In the light of the above facts, this research was conducted, the study aimed at determining the impact of storage conditions on physical features \& cooking traits of the white rice coarse \& aromatic varieties

\section{Materials and Methods}

\section{Collection of samples}

Paddy samples of three varieties (one aromatic and two coarse, Lateefy, DR-82 and IR-6) were collected from RRI, Dokri, Sindh and aromatic BS-385 was taken from Rice Research Institute Kala Shah Kaku Punjab, Pakistan. The paddy rice was dried and cleaned before de-hulling.

\section{Sample preparation}

To obtain the white rice the stake sheller was used to de-hull the paddy rice. After de-hulling the samples 
of white rice were dried at room temperature $(25 \pm 1$ ${ }^{\circ} \mathrm{C}$ ) for 24 hours. Afterward rice samples were filled in 3 different packaging materials i.e. gunny, cotton, and nylon bags, then kept at $20 \pm 1{ }^{\circ} \mathrm{C}$ in cold storage room for a period of one year at the IFST, SAU, Tandojam, Sindh Pakistan. Physical \& cookery analysis were done on freshly milled rice and stored samples on quarterly basis as for 3, 6, 9 and 12 months.

\section{Evaluation physico-chemical parameters}

Moisture (\%): Water content was estimated by placing $100 \mathrm{~g}$ sample of each in oven at $105 \pm 5^{\circ} \mathrm{C}$ temperature (AACC, 2000 method No.44-15 A).

1000-grain weight $(\mathrm{g})$ : To record the thousand grain weight of fresh and stored rice, 50 gram sample of each variety was taken, counted and 1000 seed weight (g) was noted on electric balance.

Gel consistency ( $\mathbf{m m})$ : The GC was assessed by the process recommended by Cagampang et al. (1973). The white rice was crushed into fine powder. Rice powder weighing $100 \mathrm{mg}$ was transferred into test tube measuring $2 \times 19.5 \mathrm{~cm}$ to ethanol $5(0.2 \mathrm{ml})$ along with thymol blue $(0.25 \%)$ subsequently the solution of $\mathrm{KOH}$ measuring $2.0 \mathrm{~mL}$ (2.8gin distilled water i.e., $250 \mathrm{~mL}$ ) was added. The blend was retained for eight minutes in the tank of boiling water. Subsequently, it was kept for five minutes for normal cooling. Lastly, sample was placed for twenty minutes in the ice bath. Afterwards test tubes were detached, the samples were saved in straight form for one hour \& grid paper was utilized for measurement. Pertaining to gel consistency $(\mathrm{mm})$, it is explained that a measure of the flow characteristics of rice gel $(100 \mathrm{mg})$ in $2 \mathrm{ml}$ of $0.2 \mathrm{~N} \mathrm{KOH}$ and is indexed by the length of the horizontal gel in $\mathrm{mm}$ in a $13 \times 100 \mathrm{ml}$ test tube. This test separates rice in hard (length $36 \mathrm{~mm}$ or less) intermediate (length $36-50 \mathrm{~mm}$ ) and soft (length over $50 \mathrm{~mm}$ ) gel consistency.

\section{Cooking superiority assessment}

Cooking characteristics of each rice variety was evaluated by following different parameters as explained below:

Volume Expansion Ratio (VER) and Water Absorption Ratio (WAR)

The extent ratio of each cooked rice variety was observed by the method of Juliano (1971). The VER was performed by separating the volume of the boiled rice over the uncooked rice. However, WAR was attained separating mass of baked rice over the uncooked. To measure the volume expansion ratio of cooked rice, ten gram 10-gram rice grains of each variety were taken in $100 \mathrm{~mL}$ cylinder (in triplicate) already filled with $50 \mathrm{~mL}$ of water. Water \& rice volume was together expanded in the measuring cylinder and afterward upsurge in volume was noted. However, in the 2nd group, samples were sodden in the water, after thirty minutes samples were boiled for ten minutes. Thereafter, the water was immediately filtered and mixed with cold water. To drain water completely, the boiled rice was passed through strainer $\&$ then put over the filter paper. After complete drained, Same process of raw rice was used to determine the cooked rice volume. Cooked rice Water absorption \& Volume expansion was noted by using the following formula:

$$
\begin{aligned}
W A & =\frac{W C R-W R R}{W R R} \\
V E & =\frac{H C R-H R R}{H R R}
\end{aligned}
$$

WA: Water absorption; WCR: Weight of cooked rice; WRR: Weight of raw rice; VE: Volume expansion; HCR: Height of cooked rice; HRR: Height of raw rice.

\section{Statistical analysis}

Tests were carried out utilizing 3 imitates, the obtained data was statistically analyzed by the software package Statistix 8.1. (2003).

\section{Results and Discussion}

\section{Moisture (\%)}

The results regarding the moisture content among different varieties (aromatic and coarse), packaging material and time intervals was significantly $(P<0.05=$ $0.000)$ varied. Table 1 indicted moisture content of aromatic BS-385 was increased during the storage period, it was $10.76 \%$ at fresh level while, $18.60 \%$ was noted in cotton bag after one year whereas, 10.76 to $17.00 \%$ in gunny \& nylon respectively. The increase was also observed in DR-82, at the initial stage $11.57 \%$ was determined, however, $18.27 \%$ was observed in cotton and 11.57 to $17.07 \%$ in gunny and 11.57 to $18.00 \%$ in nylon. Moisture content of coarse IR-6 was increased, at fresh level it was $12.13 \%$ while $17.80 \%$ was found after one year in cotton, 12.13 to $17.43 \%$ in gunny and in nylon from 12.13 to $17.40 \%$. 
Table 1: Moisture content (\%) of different rice varieties affected by different packaging materials and storage time.

\begin{tabular}{|c|c|c|c|c|c|c|c|}
\hline \multirow[t]{2}{*}{ Varieties } & \multirow{2}{*}{$\begin{array}{l}\text { Packaging } \\
\text { material }\end{array}$} & \multicolumn{6}{|c|}{ Storage intervals (months) } \\
\hline & & Fresh (0 days) & 3 Months & 6 Months & 9 Months & 12 Months & Means \\
\hline \multirow[t]{3}{*}{ BS-385 } & Cotton & $10.76^{\mathrm{v}}$ & $16.47^{n}$ & 19.00 cde & 18.60. ${ }^{\mathrm{efg}}$ & 18.60 efg & $16.68^{a}$ \\
\hline & Gunny & $10.77^{v}$ & $15.77^{\circ}$ & 18.60 efg & $17.00^{\mathrm{m}}$ & $17.00^{\mathrm{m}}$ & $15.82^{f}$ \\
\hline & Nylon & $10.77^{v}$ & 15.50 op & $19.00^{\text {cde }}$ & $17.00^{\mathrm{m}}$ & $17.07^{\mathrm{m}}$ & 15.86 ef \\
\hline \multirow[t]{4}{*}{ DR-82 } & Cotton & 11.57 u & $14.20^{\mathrm{rs}}$ & $19.60 \mathrm{ab}$ & $18.40 \mathrm{fgh}$ & 18.27 ghi & $16.40^{\mathrm{cd}}$ \\
\hline & Gunny & $11.57^{\text {u }}$ & $15.73^{\circ}$ & 19.17 bcd & $17.20^{\mathrm{lm}}$ & $17.07^{\mathrm{m}}$ & $16.14^{\mathrm{cd}}$ \\
\hline & Nylon & $11.57^{\text {u }}$ & 14.77 q & $20.00^{a}$ & $18.00 \mathrm{hij}$ & $18.00^{\mathrm{hij}}$ & $16.46^{\mathrm{ab}}$ \\
\hline & Cotton & $12.13^{\mathrm{t}}$ & 14.70 qr & $18.80 \mathrm{def}$ & 18.00 hij & $17.80^{\mathrm{ijk}}$ & $16.28^{a}$ \\
\hline \multirow[t]{2}{*}{ IR-6 } & Gunny & $12.13^{\mathrm{t}}$ & $15.00 \mathrm{pq}$ & $19.33 \mathrm{bc}$ & $17.40^{\mathrm{klm}}$ & $17.43^{\mathrm{klm}}$ & $16.26^{b c}$ \\
\hline & Nylon & $12.13^{t}$ & $13.73^{\mathrm{s}}$ & 19.00 cde & $17.40^{\mathrm{klm}}$ & $17.40^{\mathrm{klm}}$ & $15.93^{b}$ \\
\hline \multirow[t]{3}{*}{ Lateefy } & Cotton & $11.10^{\mathrm{uv}}$ & $15.67^{\circ}$ & $19.20 \mathrm{bcd}$ & $18.80^{\mathrm{def}}$ & $17.47 \mathrm{klm}$ & $16.44^{b}$ \\
\hline & Gunny & $11.10^{\mathrm{uv}}$ & $15.53^{\circ}$ & $19.00^{\text {cde }}$ & $17.07 \mathrm{~m}$ & $17.40^{\mathrm{klm}}$ & $16.02 \mathrm{def}$ \\
\hline & Nylon & $11.10^{\mathrm{uv}}$ & 14.73 q & $19.40^{b c}$ & $17.60^{\mathrm{jkl}}$ & $17.60^{\mathrm{jkl}}$ & $16.08^{\mathrm{de}}$ \\
\hline Mean & & $11.39^{d}$ & $15.15^{\mathrm{c}}$ & $19.17^{a}$ & $17.76^{\mathrm{b}}$ & $17.59^{\mathrm{b}}$ & \\
\hline SE & 0.2559 & & & & & & 0.1144 \\
\hline LSD 5\% & 0.5067 & & & & & & 0.2266 \\
\hline
\end{tabular}

Aromatic Lateefy showed increase, $11.10 \%$ was noted at fresh level, whereas, $17.47 \%$ was observed after one year in cotton bag, 11.10 to $17.40 \%$ in gunny and 11.10 to 17.60 in nylon respectively. The moisture content of all varieties was significantly increased in the one year storage period. Main reason of the moisture increase was due to the moisture exchange between the white rice and its storge environments. Storage circumstances resulted in increased moisture, storing rice grains at cold temperature gave the highest moisture content (\%) of milled grains (E1-Kady et al., 2013). Wangspa et al. (2018) has stated that the storage-induced changes in the moisture content. Among all the varieties, higher moisture contents (20.00\%) was noted in coarse variety DR-82, when it was packed in nylon bag for 6 months duration, surpassed by $19.60 \%$ in same variety at same time period in cotton bag. While, in aromatic varieties high moisture content (19.40\%) was recorded in Lateefy at 6 months storage period packed in Nylon bag; however, at the same time it was also observed in gunny bag $(19.20 \%)$ in the same variety. The lowest moisture content $(10.76 \%)$ was recorded in aromatic rice variety, Basmati Super (BS-385) at fresh level. The trends of moisture contents during the storage period were found declined after nine months in cotton and gunny packaging materials. Due to high grain moisture content, the susceptibility to pest and insect attack was increased during storage (Champagne et al., 1997), even though, it has been reported that at $15 \%$ of moisture content gives more flavour to rice and the impact of rice brightness on taste density is related to additional moisture provided. The storage period affects the quality of rice due to swelling of starch granule has also been reported by Katekhong and Charoenrein (2012).

\section{0-grain weight}

The results of the 1000-grain weight $(\mathrm{g})$ of all the varieties regarding the packaging, material and time intervals was significant $(P<0.05=0.000)$ and presented in Table 2 . The 1000 -grain weight of aromatic BS-385 during the storage was increased, $16.60 \mathrm{~g}$ was noted at fresh level, whereas, after one year $17.50 \mathrm{~g}$ was determined in cotton bag while in nylon and gunny from 16.60 to $17.10 \mathrm{~g}$ respectively, decrease was found in coarse DR-82 from 20.70 to $20.60 \mathrm{~g}$ in cotton, 20.73 to $19.30 \mathrm{~g}$ in gunny and 20.60 to $19.53 \mathrm{~g}$ in nylon. Grain weight of the coarse IR-6 was decreased, at initial stage it was $21.30 \mathrm{~g}$ while, $21.20 \mathrm{~g}$ in cotton bag was noted after one year. Whereas, in gunny from 21.30 to $20.00 \mathrm{~g}$, it was increased in nylon from 21.30 to $21.80 \mathrm{~g}$ respectively. The aromatic Lateefy showed increase in 1000-grain weight in cotton bag at fresh level it was $14.90 \mathrm{~g}$ while, $16.00 \mathrm{~g}$ was observed after one year, while in gunny and nylon from 14.90 to $15.60 \mathrm{~g}$ respectively. Significant change was observed in the 1000-grain kernel weight of the varieties 
Table 2: 1000-grain weight (g) of rice varieties affected by different packaging materials and storage time.

\begin{tabular}{|c|c|c|c|c|c|c|c|}
\hline \multirow[t]{2}{*}{ Variety } & \multirow{2}{*}{$\begin{array}{l}\text { Packaging } \\
\text { material }\end{array}$} & \multicolumn{6}{|c|}{ Storage Intervals (months) } \\
\hline & & Fresh (0 days) & 3 Months & 6 Months & 9 Months & 12 Months & Mean \\
\hline \multirow{3}{*}{ BS-385 } & Cotton & $16.06^{\text {no }}$ & $18.00{ }^{\mathrm{jk}}$ & $18.03^{j}$ & $17.50^{\mathrm{jkl}}$ & $17.50^{\mathrm{jkl}}$ & $17.40^{\mathrm{e}}$ \\
\hline & Gunny & $16.06^{\text {no }}$ & $18.00 \mathrm{jk}$ & $18.00 \mathrm{jk}$ & $17.10^{\mathrm{j}-\mathrm{m}}$ & $17.10^{\mathrm{j}-\mathrm{m}}$ & $17.28^{\mathrm{e}}$ \\
\hline & Nylon & $16.06^{\text {no }}$ & $18.00^{\mathrm{jk}}$ & $17.40^{\mathrm{jkl}}$ & $17.00^{k-n}$ & $17.10^{\mathrm{j}-\mathrm{m}}$ & $17.12^{\text {ef }}$ \\
\hline \multirow{3}{*}{ DR-82 } & Cotton & 20.70 fgh & $25.00^{a}$ & 19.90 ghi & $20.70 \mathrm{fgh}$ & $20.60 \mathrm{fgh}$ & $21.36^{b}$ \\
\hline & Gunny & $20.73^{f g h}$ & $25.00^{a}$ & $19.70 \mathrm{hi}$ & $19.26^{\mathrm{i}}$ & $19.30^{\mathrm{i}}$ & $20.79^{d}$ \\
\hline & Nylon & $20.60^{\mathrm{fgh}}$ & $25.00^{\mathrm{a}}$ & 19.70 ghi & $19.50^{\mathrm{i}}$ & $19.53^{i}$ & $20.89^{c d}$ \\
\hline \multirow{3}{*}{ IR-6 } & Cotton & $21.30^{\text {ef }}$ & $24.00^{\mathrm{ab}}$ & 22.00 cde & $21.50 \mathrm{def}$ & 21.20 ef & $21.99^{\mathrm{a}}$ \\
\hline & Gunny & 21.30 ef & $23.00 \mathrm{bc}$ & $22.30^{\mathrm{cd}}$ & 20.00 ghi & 20.00 ghi & $21.32^{b c}$ \\
\hline & Nylon & 21.30 ef & $23.00^{b c}$ & 21.20 ef & $21.80^{\text {de }}$ & $21.80 \mathrm{de}$ & $21.82^{a}$ \\
\hline \multirow{3}{*}{ Lateefy } & Cotton & $14.90^{\mathrm{p}}$ & $20.10 \mathrm{ghi}$ & $16.60^{1-o}$ & $16.40^{\mathrm{mno}}$ & 16.00 no & $16.80^{f}$ \\
\hline & Gunny & $14.90^{\mathrm{P}}$ & $16.00^{\text {no }}$ & $16.00^{\text {no }}$ & $15.70^{\circ p}$ & $15.60^{\circ p}$ & $15.64^{h}$ \\
\hline & Nylon & $14.90^{p}$ & $18.00^{\mathrm{jk}}$ & $16.80^{\mathrm{lmn}}$ & $15.70^{\circ p}$ & $15.60^{\circ p}$ & $16.20^{\mathrm{g}}$ \\
\hline Mean & & $18.24^{\mathrm{c}}$ & $21.092^{\mathrm{a}}$ & $18.98^{b}$ & $18.50^{c}$ & $18.45^{\mathrm{c}}$ & \\
\hline $\mathrm{SE}$ & 0.5169 & & & & & & 0.2311 \\
\hline LSD 5\% & 1.0234 & & & & & & 0.4577 \\
\hline
\end{tabular}

with change in moisture content. Gharekhani et al. (2013), has reported the variation of thousand grain weight with the moisture content from 15.11 to 21 . $5 \mathrm{~g}$ in white rice of Fajar and from 16.96 to $21 \mathrm{~g}$ in Tarom white rice from 5 to $37 \%$ weight basis (w.b) rise in moisture content. El-Kady et al. (2013) has reported significantly decrease in the 1000 -pady grain by increasing storage period. Among all varieties the higher 1000-grain weight $(25.00 \mathrm{~g})$ of DR-82 was observed at 3 months storage period when kept in cotton, nylon and gunny bags followed by other coarse variety IR-6 at 3 months storage $(23.00 \mathrm{~g})$ in gunny and nylon bags, respectively. However, in aromatic varieties lowermost grain weight $(14.90 \mathrm{~g})$ was noted in Lateefy at fresh level. After 6 months storage period, 1000-grain weight showed decline trend in all varieties and packaging materials. Previous studies have suggested that between 20 and $30 \mathrm{~g}$ weights of 1000 grains are measured better; whereas, the lower weight by $20 \mathrm{~g}$ indicated the occurrence of immature damage grains (Perdon et al., 1997). Similarly, AduKwarteng et al. (2003) revealed that, physical quality of rice grain dependent on the grain length, weight and width. The variation in grains weight varies between 14.5 to $18.5 \mathrm{~g} ; 16.97$ to $24.54 \mathrm{~g}$ has also been reported by different researchers in the literature which support our study (Thomas et al., 2013; Shabbir et al. (2008); Bian et al., 2013).

\section{Gel consistency ( $\mathrm{mm}$ )}

The results pertaining to gel consistency at Table 3 showed significant $(P<0.05=0.000)$ differences among all varieties, packaging material and time intervals. Higher gel consistency $(92.00 \mathrm{~mm})$ was noted in aromatic rice variety, BS-385, at 9 months storage period in cotton bag. Whereas, at the same time period it was determined $(90.00 \mathrm{~mm})$ in coarse rice variety IR-6 packed in cotton bag. However, among coarse varieties, the lowest gel consistency was observed in IR-6 $(48.00 \mathrm{~mm})$ at 3 months storage period in nylon bag. The trend of gel consistency of all varieties showed increase from 6 to 9 months storage period in all packages. After 12 months high mean value was noted in coarse variety DR-82 (79.40) packed in cotton bag. The GC ( $\mathrm{mm})$ results indicates that all varieties were medium and soft with the gel length values between 45.00 to $94.00 \mathrm{~mm}$. Many coarse and aromatic rice varieties having similar amylose contents and physical dimensions like the size of grain its shape and look, therefore, it is difficult to classify them exactly. Gel consistency is the only reliable test which differentiates such rice varieties. Literature also reveals that intermediate amylose rice with softer gel consistency is preferred because of their more tenderness. Sagar et al. (1988) reported gel consistency ranges from 33 to $67 \mathrm{~mm}$ in coarse and aromatic varieties. With the increase of time of rice storage, eventually reduces the elasticity though the grain hardness and adhesion 
Table 3: Gel consistency $(\mathrm{mm})$ of different rice affected by different packaging materials and storage time.

\begin{tabular}{|c|c|c|c|c|c|c|c|}
\hline \multirow[t]{2}{*}{ Varieties } & \multirow{2}{*}{$\begin{array}{l}\text { Packaging } \\
\text { Material }\end{array}$} & \multicolumn{6}{|c|}{ Storage Intervals (months) } \\
\hline & & Fresh (0 days) & 3 Months & 6 Months & 9 Months & 12 Months & Mean \\
\hline \multirow[t]{3}{*}{ BS-385 } & Cotton & $80.0^{\text {cde }}$ & $65.0^{\mathrm{gh}}$ & $80.0^{\text {cde }}$ & $85.0^{\mathrm{abc}}$ & $80.0^{\text {cde }}$ & $78.00^{\mathrm{abc}}$ \\
\hline & Gunny & $80.0^{\text {cde }}$ & $68.0^{\mathrm{fgh}}$ & $71.6^{\text {efg }}$ & $80.0^{\text {cde }}$ & $80.0^{\text {cde }}$ & $75.93^{a b c}$ \\
\hline & Nylon & $80.0^{\text {cde }}$ & $50.0^{\mathrm{jk}}$ & 74.0 def & $75.0^{\text {def }}$ & $75.0^{\text {def }}$ & $70.86^{\text {de }}$ \\
\hline \multirow[t]{3}{*}{ DR-82 } & Cotton & $65.0^{\mathrm{gh}}$ & $60.0^{\text {hi }}$ & $90.0^{\mathrm{ab}}$ & $92.0^{\mathrm{a}}$ & $90.0^{\mathrm{ab}}$ & $79.40^{a}$ \\
\hline & Gunny & $65.0^{\mathrm{gh}}$ & $65.0^{\mathrm{gh}}$ & $80.0^{\text {cde }}$ & $84.0^{a b c}$ & $80.0^{\text {cde }}$ & $74.80^{\mathrm{bc}}$ \\
\hline & Nylon & $65.0 \mathrm{gh}$ & $55.0 \mathrm{ij}$ & 75.0 def & $80.0^{\text {cde }}$ & $70.0^{\mathrm{fg}}$ & 69.00 ef \\
\hline \multirow{3}{*}{ IR-6 } & Cotton & $60.0^{\text {hi }}$ & $70.0^{\mathrm{fg}}$ & $88.0^{a b c}$ & $90.0^{a b}$ & $85.0^{a b c}$ & $78.60^{a b}$ \\
\hline & Gunny & $60.0^{\mathrm{hi}}$ & $65.0^{\mathrm{gh}}$ & $85.0^{a b c}$ & $82.0^{b c d}$ & $80.0^{\text {cde }}$ & $74.40^{\mathrm{cd}}$ \\
\hline & Nylon & $60.0^{\text {hi }}$ & $48.3^{\mathrm{jk}}$ & $80.0^{\text {cde }}$ & $84.0^{a b c}$ & $80.0^{c d}$ & $70.53^{\mathrm{e}}$ \\
\hline \multirow[t]{3}{*}{ Lateefy } & Cotton & $60.0^{\mathrm{hi}}$ & $50.0^{\mathrm{jk}}$ & $75.0 \mathrm{de}$ & $80.0^{\text {cde }}$ & $85.0^{a b c}$ & $70.00^{\mathrm{e}}$ \\
\hline & Gunny & $60.0^{\text {hi }}$ & $45.0^{\mathrm{k}}$ & $70.0^{\mathrm{fg}}$ & $75.0^{\text {def }}$ & $70.0^{\mathrm{fg}}$ & $64.00^{g}$ \\
\hline & Nylon & $60.0^{\text {hi }}$ & $50.0^{\mathrm{jk}}$ & $71.6^{\text {efg }}$ & $74.0^{\text {def }}$ & $75.0^{\text {def }}$ & $66.13^{\mathrm{fg}}$ \\
\hline Mean & & $78.36^{c}$ & $57.61^{d}$ & $78.36^{\mathrm{b}}$ & $81.78^{a}$ & $79.19^{b}$ & \\
\hline $\mathrm{SE}$ & 4.30 & & & & & & 1.9210 \\
\hline LSD 5\% & 8.50 & & & & & & 3.8035 \\
\hline
\end{tabular}

Table 4: Water absorption ratio of different rice varieties affected by different packaging materials and storage time.

\begin{tabular}{|c|c|c|c|c|c|c|c|}
\hline \multirow[t]{2}{*}{ Varieties } & \multirow{2}{*}{$\begin{array}{l}\text { Packaging } \\
\text { Material }\end{array}$} & \multicolumn{6}{|c|}{ Storage Intervals (months) } \\
\hline & & Fresh (0 days) & 3 Months & 6 Months & 9 Months & 12 Months & Mean \\
\hline \multirow[t]{3}{*}{ BS-385 } & Cotton & $3.80^{a}$ & 3.00 cde & $2.70^{\mathrm{e}-\mathrm{h}}$ & $2.70^{\mathrm{d}-\mathrm{h}}$ & $2.60^{\mathrm{e}-\mathrm{h}}$ & $2.96^{\mathrm{ab}}$ \\
\hline & Gunny & $3.80^{a}$ & $3.10^{\mathrm{bcd}}$ & $2.80^{\mathrm{d}-\mathrm{g}}$ & $2.80^{\mathrm{c}-\mathrm{g}}$ & $2.73^{\mathrm{d}-\mathrm{h}}$ & $3.04^{\mathrm{ab}}$ \\
\hline & Nylon & $3.80^{\text {a }}$ & $3.10^{b c d}$ & $3.50 \mathrm{ab}$ & $3.50^{\mathrm{ab}}$ & $2.40 \mathrm{gh}$ & $3.10^{\text {a }}$ \\
\hline \multirow[t]{3}{*}{ DR-82 } & Cotton & $2.90^{\mathrm{e}-\mathrm{h}}$ & $2.60^{\mathrm{e}-\mathrm{h}}$ & $2.30^{\mathrm{h}}$ & $2.50 \mathrm{fgh}$ & $2.50 \mathrm{fgh}$ & $2.56^{\mathrm{d}}$ \\
\hline & Gunny & $2.90^{\mathrm{e}-\mathrm{h}}$ & $2.90^{\mathrm{c}-\mathrm{f}}$ & $2.47 \mathrm{fgh}$ & $2.50 \mathrm{fgh}$ & $2.40^{\mathrm{gh}}$ & $2.63^{d}$ \\
\hline & Nylon & $2.90^{\mathrm{e}-\mathrm{h}}$ & $2.90^{\mathrm{c}-\mathrm{f}}$ & $2.50 \mathrm{fgh}$ & $3.07 \mathrm{bcd}$ & $2.90^{c-f}$ & $2.85^{b c}$ \\
\hline \multirow[t]{3}{*}{ IR-6 } & Cotton & $3.20^{b c}$ & $2.50 \mathrm{fgh}$ & $2.30^{\mathrm{h}}$ & $2.60^{\mathrm{e}-\mathrm{h}}$ & $2.50 \mathrm{fgh}$ & $2.62^{d}$ \\
\hline & Gunny & $3.20^{b c}$ & 2.97 cde & $2.30^{\mathrm{h}}$ & $2.60^{\mathrm{e}-\mathrm{h}}$ & $2.60^{\mathrm{e}-\mathrm{h}}$ & $2.73^{\mathrm{cd}}$ \\
\hline & Nylon & $3.20^{b c}$ & $2.90^{c-f}$ & $2.80^{c-g}$ & $2.80^{\mathrm{c}-\mathrm{g}}$ & $2.70^{\mathrm{d}-\mathrm{h}}$ & $2.88^{b c}$ \\
\hline \multirow[t]{3}{*}{ Lateefy } & Cotton & $3.50^{\mathrm{ab}}$ & $2.90^{c-f}$ & $2.43 \mathrm{gh}$ & $2.50 \mathrm{fgh}$ & $2.43 \mathrm{gh}$ & $2.75^{\mathrm{cd}}$ \\
\hline & Gunny & $3.50^{\mathrm{ab}}$ & $3.10^{b c d}$ & $2.50 \mathrm{fgh}$ & $2.90^{c-f}$ & $2.80^{c-g}$ & $2.96^{\mathrm{ab}}$ \\
\hline & Nylon & $3.50^{\mathrm{ab}}$ & $3.10^{\mathrm{bcd}}$ & $2.50 \mathrm{fgh}$ & $3.10 \mathrm{bcd}$ & 3.00 cde & $3.04^{\mathrm{ab}}$ \\
\hline Mean & & $3.35^{\mathrm{a}}$ & $2.92^{\mathrm{b}}$ & $2.52^{c}$ & $2.79^{\mathrm{b}}$ & $2.53^{c}$ & \\
\hline $\mathrm{SE}$ & 0.2329 & & & & & & 0.1041 \\
\hline LSD 5\% & 0.4610 & & & & & & 0.2062 \\
\hline
\end{tabular}

increase initially afterwards shows the reduction has also reported by Wang et al. (2017).

\section{Cooking characteristics}

Water absorption ratio: The results presented in $\mathrm{Ta}-$ ble 4 pertaining to Water Absorption Ratio (WER), higher WER (3.80 and 3.50\%) was observed in aromatic rice varieties, BS-385 and Lateefy at fresh level, respectively. While, the lowest water absorption $(2.47 \%)$ was determined in coarse variety, DR-82 at 6 months storage time period packed in gunny bag. The decreased in the water absorption ratio was found in all rice varieties after 3 months storage period in all packaging materials. Findings of the current investigations are well aligned with Gee et al. (2005) who reported the similar trend of water absorption ratio from 3.96 to $6.8 \%$ and Shabbir et al. (2008) observed WAR ranged from 2.29 to $2.96 \%$ in the coarse and aromatic rice varieties. 
Table 5: Volume expansion ratio of different rice varieties affected by different packaging materials and storage time.

\begin{tabular}{|c|c|c|c|c|c|c|c|}
\hline \multirow[t]{2}{*}{ Varieties } & \multirow{2}{*}{$\begin{array}{l}\text { Packaging } \\
\text { Material }\end{array}$} & \multicolumn{6}{|c|}{ Storage Intervals (months) } \\
\hline & & Fresh (0 days) & 3 Months & 6 Months & 9 Months & 12 Months & Mean \\
\hline \multirow[t]{3}{*}{ BS-385 } & Cotton & $4.20^{c}$ & $3.50^{d}$ & 2.50 ef & 2.50 ef & $2.60^{\mathrm{e}}$ & $3.06^{\mathrm{b}}$ \\
\hline & Gunny & $4.20^{c}$ & $3.50^{\mathrm{d}}$ & 1.80 ghi & $0.90^{k}$ & $1.20^{\mathrm{jk}}$ & 2.32 ef \\
\hline & Nylon & $4.20^{c}$ & $3.50^{d}$ & $1.70 \mathrm{hi}$ & $0.90^{\mathrm{k}}$ & $1.00^{\mathrm{k}}$ & $2.26^{\mathrm{efg}}$ \\
\hline \multirow[t]{3}{*}{ DR-82 } & Cotton & $3.23^{\mathrm{d}}$ & $0.93^{k}$ & $0.80^{k}$ & $2.07^{\mathrm{g}}$ & $2.10^{\mathrm{fg}}$ & $1.82^{\mathrm{h}}$ \\
\hline & Gunny & $3.23^{d}$ & 1.70 ghi & 1.83 ghi & 2.50 ef & $2.53^{\mathrm{e}}$ & $2.36^{\text {ef }}$ \\
\hline & Nylon & $3.23 \mathrm{~d}$ & $3.47^{\mathrm{d}}$ & $2.60^{\mathrm{e}}$ & $1.70 \mathrm{ghi}$ & $1.93^{\mathrm{gh}}$ & $2.58^{\mathrm{cd}}$ \\
\hline \multirow[t]{3}{*}{ IR-6 } & Cotton & $4.20^{c}$ & $5.70^{a}$ & 1.60 hij & $0.80^{k}$ & $0.90^{k}$ & $2.64^{\mathrm{c}}$ \\
\hline & Gunny & $4.20^{c}$ & $4.20^{c}$ & 1.80 ghi & $1.73^{\mathrm{hi}}$ & $1.80^{\mathrm{hi}}$ & $2.42 \mathrm{de}$ \\
\hline & Nylon & $4.20^{c}$ & $1.70 \mathrm{ghi}$ & $1.70^{\mathrm{hi}}$ & $1.90^{\mathrm{hi}}$ & $2.00^{\mathrm{gh}}$ & $2.30^{\mathrm{efg}}$ \\
\hline \multirow[t]{3}{*}{ Lateefy } & Cotton & $3.40^{\mathrm{d}}$ & $3.40^{\mathrm{d}}$ & $1.70 \mathrm{hi}$ & $4.80^{\mathrm{b}}$ & $4.80^{\mathrm{b}}$ & $3.64^{a}$ \\
\hline & Gunny & $3.40^{\mathrm{d}}$ & $3.40^{\mathrm{d}}$ & 1.80 ghi & $0.90^{\mathrm{k}}$ & $1.00^{\mathrm{k}}$ & $2.12^{\mathrm{g}}$ \\
\hline & Nylon & $3.40^{\mathrm{d}}$ & $2.70^{\mathrm{e}}$ & $1.70 \mathrm{hi}$ & $1.70^{\mathrm{ij}}$ & $1.70 \mathrm{ghi}$ & $2.20^{\mathrm{fg}}$ \\
\hline Mean & & $3.76^{\mathrm{a}}$ & $3.01^{\mathrm{b}}$ & $1.79^{\mathrm{d}}$ & $1.85^{\mathrm{d}}$ & $1.97^{c}$ & \\
\hline SE & 0.2101 & & & & & & 0.0940 \\
\hline LSD 5\% & 0.416 & & & & & & 0.1860 \\
\hline
\end{tabular}

Volume expansion ratio: The results of all varieties regarding the Volume Expansion Ratio is presented at Table 5 revealed the higher volume expansion ratio (5.70) was noted in coarse rice variety IR-6 at 3 months storage in cotton bag followed by (4.20) of aromatic BS-385 and coarse IR-6 at fresh level. The lowest volume expansion ratio (0.80) was observed in coarse DR-82 in cotton at 6 months storge and $(0.90)$ of IR- 6 in cotton at 12 months in cotton. Afterward 3 months period volume expansion ratio trend declined up to 12 months period. In the previous study, Yousaf (1992) had found noteworthy difference in volume increase among stored and fresh rice. It was also reported that volume of grain is affected by the time of storage (Ge et al., 2005) (Verma et al., 2015). Shabbir et al. (2008) has observed the VER 3.20 in BS-85, 3.64 in IR-6, 3.08 in BS-370 and 2.35 in KS-282 respectively.

\section{Conclusions and Recommendations}

Results of the present study shows that the moisture content was highly increased in coarse varieties. Similarly, the grain weight of both aromatic and coarse varieties was also increased. Physical \& culinary quality characteristics of all rice varieties were largely affected by the storage environments, time period and packaging material. The results of the current investigations maybe useful in relation to the selection of packaging materials for rice exporters and the storage temperature for long-term storage. These findings can be beneficial to the growers and households for safe storage of white rice regarding the physical and cooking quality attributes.

\section{Novelty Statment}

Pakistan is the top rice producing country and exporter in the world. Rice is our second important cereal after wheat, four different rice varieties (aromatic \& coarse) were stored for 12 months in the controlled temperature in three different packaging materials. This very new research work will be helpful in the selection of packaging materials and storing circumstances for the rice storage.

\section{Author's Contribution}

This work was carried out under the supervision of Dr. Saghir Ahmed Sheikh and co-supervision of Dr. Aijaz Hussain Soomro and Dr. Shamsuddin Tunio. The laboratory work was conducted by Nazeer Ahmed Lashari.

\section{Conflict of Interest}

There is no potential conflict of interest

\section{References}

AACC. 2000. Approved Methods of the American Association of Cereal Chemists, American 
Association of Cereal Chemists, Inc. St. Paul, MN, USA.

Adu-kwarteng, E., W.O. Ellis, I. Oduro and J.T. Manful. 2003. Rice grain quality: a comparison of local varieties with new varieties under study in Ghana. Food Control., 14: 507-514. https:// doi.org/10.1016/S0956-7135(03)00063-X

Ahmad, M. 2001. Agricultural productivity growth differential in Punjab, Pakistan. A district level data. Pak. Dev. Rev., 40: 1-25. https://doi. org/10.30541/v40i1pp.1-25

Atungulu, G.G., Kolb, R.E., J. Karcher and Z.M Shad. 2019. Postharvest technology: Rice storage and cooling conservation. In Rice (pp. 517555). AACC International Press. https://doi. org/10.1016/B978-0-12-811508-4.00016-2

Bhattacharjee, P., S.R. Singhal and R.P. Kulkarni. 2002. Basmati rice. A review. Int. J. Food Sci. and Tech., 37 (1): 1-12. https://doi.org/10.1046/ j.1365-2621.2002.00541.x

Bian, J.M., H. Shi, C.J. Li, C.L. Zhu, Q.Y. Yu, X.S. Peng, J.R. Fu, X.P. He, X.R. Chen, L.F. Hu, L.J. Ouyang and H.H. He. 2013. QTL mapping and correlation analysis for 1000-grain weight and percentage of grains with chalkiness in rice. J. Genet., 92 (2): 281-287. https://doi. org/10.1007/s12041-013-0267-6

Butt, M.S., F.M. Anjum, M. Salim-ur-Rehman, M.K. Tahir-Nadeem and M.S. Anwer. 2008. Selected quality attributes of fine basmati rice: effect of storage history and varieties. Int. J. Food Prop., 11(3): 698-711. https://doi. org/10.1080/10942910701622706

Cagampang, G.B., C.M. Perez and B.O. Juliano. 1973. A gel consistency test for eating quality in rice. J. Sci. Food Agric., 24 (12): 1589 -1594. https://doi.org/10.1002/jsfa.2740241214

Champagne, E.T., L. Karen, B. Bet. and T. Vinyard. 1997. Effects of drying conditions, final moisture content and degree of milling on rice flavor. J. Cereal Chem., 74(5): 566-570. https://doi. org/10.1094/CCHEM.1997.74.5.566

El-Kady A.A., S.H. Abou Khadra, Nessreen N.Bassuony and H. M. Hassan, 2013. Effect of storage conditions on grain quality characters of some special rice varieties. Egypt J. Plant Breed., 17(4): 70 - 84. https://doi.org/10.12816/0004001

FAOSTAT. 2019. FAO Statistical databases. Food and Agriculture Organization of the United $\mathrm{Na}$ tions http://www.fao.org

Ge. X.J., Y.Xing, C.G. Xu and Y.Q.He. 2005. QTL analysis of cooked rice grain elongation, volume expansion, and water absorption using a recombinant inbred population. Plant Breed., 12(2):121-126. https://doi.org/10.1111/j.14390523.2004.01055.x

Gharekhani M., M. Kashaninejad., A.D. Garmakhany and A. Ranjbari 2013. Physical and aerodynamic properties of paddy and white rice as a function of moisture content. Qual. Assur. Saf. Crops Foods., 5(3):187-197. https://doi. org/10.3920/QAS2012.0129

GoP. 2019. Ministry of Finance Government of Pakistan. Chapt. 2. Agriculture, Important crops rice, $\mathrm{Pp}$. 16-17.

Gunathilake, M.D. T.L. and S. Ekanayake. 2015. Effect of different cooking methods on glycaemic index of Indian and Pakistani basmati rice varieties. https://doi.org/10.4038/cmj. v60i2.7545

Hirannaiah, B.V., M.K. Bhashyam and S.Z. Ali. 2011. An improved cooking quality test for Basmati rice. J. Food Sci. and Tech., 38: 116- 119.

Juliano, B.O. 1985. Rice Chemistry and Technology. American Association of Cereal Chemists. USA. pp: 757.

Juliano, B.O. 1971. A simplified assay for milled rice amylose. J. Cereal Sci., 16: 334- 340.

Katekhong, W. and S. Charoenrein. 2012. Effect of rice storage on pasting properties, swelling and granular morphology of rice flour. Asian J. Food Agro-Ind., 5(04): 315-321.

Kausar, G., M.K Sharif., M. Saeed and M. Shahid. 2020. Screening of Pakistani coarse rice cultivars from Punjab and Sindh for end-use quality. Pak. J. Agric. Sci., 57(4).

Khan, S.K., J. Iqbal and M. Saeed. 2013. Comparative study of grain yield and biochemical traits of different rice varieties grown under saline and normal conditions, J. Anim. Plant Sci., 23(2): 575-588.

Kumar, S. and K. Prasad. 2013. Effect of paddy parboiling and rice puffing on physical, optical and aerodynamic characteristics. Int. J. Agric. Food Sci. Technol., 4: 765-770.

Mohanty, S. 2013. Trends in global rice consumption', Rice Today, January-March.International Rice Research Institute (IRRI).

Oko, A.O. and S.I. Ugwu. 2011. The proximate and mineral compositions of five major rice varieties in Abakaliki, South-Eastern Nigeria. Inter. J. Plant Physio. Biochem., 3: 25-27. 
Perdon.A.A., B.P. Marks, T.J. Siebenmorgen and N.B. Reid. 1997. Effects of rough rice storage conditions on the amylograph and cooking properties of medium-grain rice cv. Bengal. Cereal Chem., 74(6):864-867.

Prasad, K., P. Prakash and K.K. Prasad. 2010. Rice based functional cookies for celiac: Studies on its formulation. Lambert Academic Publishing, Saarbrucken, Germany. Pp. 1-128.

Sagar, M.A., M. Ashraf and M.A. Khan. 1988. Grain quality characteristics of Pakistani commercial rice varieties. Pak. J. Agric. Res., 9: 431436.

Shabbir, M.A., F.M. Anjum, T. Zahoor and H. Nawaz. 2008. Mineral and pasting characterization of Indica rice varieties with different milling fractions. Int. J. Agri. Biol., 10: 556-560.

Shamim, F., M.A. Raza. and M. Akhtar. 2017. Grain quality attributes of new Rice Basmati lines of Pakistan. J. Appl. Agric. Biotechnol., 2(1): 37-47. https://doi.org/10.18685/ EJARD(7)1_EJARD-16-021

Statistix, 2003. Statistix 8.1 user guide, version 1.0. Analytical Software, PO Box 12185, Tallahassee FL 32317 USA. Copyright 2006@ by Analytical Software.

Tananuwong, K. and Y. Malila. 2011. Changes in physicochemical properties of organic hulled rice during storage under different conditions. J. Food Chem., 125(3): 179-185. https://doi. org/10.1016/j.foodchem.2010.08.057

Thomas, R., W.A. Wan-Nadiah and R. Bhat. 2013. Physiochemical properties, proximate composition, and cooking qualities of locally grown and imported rice varieties marketed in Penang, $\mathrm{Ma}$ laysia Int. Food Res. J., 20(3): 1345-1351.

Verma, D.K., M. Mohan, P.K. Prabhakar and P.P. Srivastav. 2015. Physico-chemical and cooking characteristics of Azad basmati. Int. Food Res. J., 22(4): 1380-1389.

Vlachos, A. and I.S. Arvanitoyannis. 2008. A review of rice authenticity/adulteration methods and results. Crit. Rev. Food Sci. Nutr., 48: 553-598. https://doi.org/10.1080/10408390701558175

Wang, L., H. Wang, Y. Yao, Y. Zhang, J. Chen, J. Shi and X.Ju. 2017. Effects of different packages on edible quality and volatile components of rice during storage. Sci. Agric. Sin., 50: 25762591.

Wangspa, W., S. Vearasilp, and Y. Chanbang. 2018. Effects of radio frequency heating and storage time on physical and chemical properties of rough rice cv. Khao Dawk Mali 105. J. Chiang Mai Univ. J. Nat. Sci., 17(2). https:// doi.org/10.12982/CMUJNS.2018.0008

Yousaf, M. 1992. Study on some physicochemical characteristics affecting the cooking and eating qualities of some Pakistani rice varieties. M.Sc. Thesis, Department of Food Technology. University of Agriculture Faisalabad. 